\title{
Article \\ Manure Source and Cropping System Affect Nutrient Uptake by Cactus (Nopalea cochenillifera Salm Dyck)
}

\author{
Felipe Martins Saraiva ${ }^{1}$, José Carlos Batista Dubeux, Jr. ${ }^{2, * \mathbb{D}}$, Márcio Vieira da Cunha ${ }^{1}{ }^{\mathbb{D}}$, Rômulo Simões \\ Cezar Menezes ${ }^{3}{ }^{\mathbb{D}}$, Mércia Virginia Ferreira dos Santos ${ }^{1}$, Dayanne Camelo ${ }^{1}$ and Ivan Ferraz ${ }^{4}$ \\ 1 Departamento de Zootecnia, Universidade Federal Rural de Pernambuco, Rua Dom Manuel de Medeiros, \\ s/n, Dois Irmãos, Recife 52171-900, PE, Brazil; felipe.saraiva@ifma.edu.br (F.M.S.); \\ marcio.cunha@ufrpe.br (M.V.d.C.); mercia.vfsantos@ufrpe.br (M.V.F.d.S.); dayanne.camelo@ufrpe.br (D.C.) \\ 2 North Florida Research and Education Center, University of Florida, 3925 Highway 71, \\ Marianna, FL 32446, USA \\ 3 Departamento de Energia Nuclear, Universidade Federal de Pernambuco, Av. Prof. Luis Freire, 1000, \\ Cidade Universitaria, Recife 50740-540, PE, Brazil; rmenezes@ufpe.br \\ 4 Instituto Agronômico de Pernambuco (IPA), Av. Gal. San Martin, 1371, Bongi, Recife 50761-000, PE, Brazil; \\ ivan.ferraz@ipa.br \\ * Correspondence: dubeux@ufl.edu
}

\section{check for} updates

Citation: Saraiva, F.M.; Dubeux, J.C.B., Jr.; Cunha, M.V.d.; Menezes, R.S.C.; Santos, M.V.F.d.; Camelo, D.; Ferraz, I. Manure Source and Cropping System Affect Nutrient Uptake by Cactus (Nopalea cochenillifera Salm Dyck). Agronomy 2021, 11, 1512. https://doi.org/ 10.3390/agronomy11081512

Academic Editors: Juan J. Villalba and Jennifer MacAdam

Received: 29 June 2021

Accepted: 27 July 2021

Published: 29 July 2021

Publisher's Note: MDPI stays neutral with regard to jurisdictional claims in published maps and institutional affiliations.

Copyright: (c) 2021 by the authors. Licensee MDPI, Basel, Switzerland. This article is an open access article distributed under the terms and conditions of the Creative Commons Attribution (CC BY) license (https:/ / creativecommons.org/licenses/by/ $4.0 /)$.

\begin{abstract}
Forage cactus responds positively to organic fertilization. However, little is known about the mineralization dynamics of the various sources of existing organic fertilizers. Thus, the objective was to evaluate the release of nutrients from different manure types and the nutrient accumulation in forage cactus across different cropping systems. Different manure sources (cattle, goat, sheep, and broiler litter) were evaluated for the following cropping systems: (i) Gliricidia sepium intercropped with cactus cv. IPA-Sertânia; (ii) Leucaena leucocephala intercropped with cactus cv. IPA-Sertânia; and (iii) Cactus cv. IPA-Sertânia in monoculture, in the tropical semiarid region of Brazil. The rate of decomposition and release of $\mathrm{N}, \mathrm{P}$, and $\mathrm{K}$ from manure was determined by incubating a litterbag, evaluated in different periods $(0,4,8,16,32,64,128$, and 256 days). Broiler litter released the greatest amount of $\mathrm{N}$ and P. Sheep manure released the greatest amounts of $\mathrm{K}$. The greatest accumulations of $\mathrm{N}$, $\mathrm{P}$, and $\mathrm{K}$ in cactus biomass occurred when broiler litter was applied. Cactus monoculture accumulated less $\mathrm{N}$ over 256 days, indicating that the presence of tree legumes favors the accumulation of $\mathrm{N}$ in cactus. Broiler litter promoted the best synchronism between $\mathrm{N}$ release and $\mathrm{N}$ uptake in different cropping systems.
\end{abstract}

Keywords: organic fertilization; semiarid; synchronism; Gliricidia sepium; Leucaena leucocephala; Nopalea cochenillifera

\section{Introduction}

Forage cactus is an important source for animal feed in different arid and semiarid regions of the world. The productivity of this crop is affected by management [1], cultivar [2], planting spacing [3], among other factors. The cultivar IPA-Sertânia (Nopalea cochenillifera Salm Dyck) is an important option in the Brazilian semiarid mainly because it is resistant to prickly pear cochineal Dactylopius opuntiae [4]. The xerophytic habit and the crassulacean acid metabolism (CAM) that leads to morphophysiological changes under adverse conditions [5] make this forage species an important alternative for areas with erratic rainfall distribution. This cactus variety is productive and is a source of energy for livestock; it is rich in non-fiber carbohydrates, total digestible nutrients, vitamins, minerals, and water. However, it has lesser fiber and protein concentrations than the typical values observed in other forages [6].

Integrating forage legumes in cactus cropping systems provides an opportunity to supply fiber and protein, in addition to increase $\mathrm{N}$ availability in the system [7]. Nitrogen 
input from biological $\mathrm{N}_{2}$ fixation benefits the nutrient cycling process by adding litter with low $\mathrm{C} / \mathrm{N}$ ratio [8], with potential improvements in the chemical, physical, and biological soil characteristics. Miranda et al. [1] observed that cactus growing near tree legumes (Gliricidia sepium and Leucaena leucocephala) produced greater biomass than cactus growing away from the trees.

Normally the cactus is harvested in the field, chopped, and fed to the animals in the trough in isolation or mixed with other ingredients of the diet [9], but it can also be supplied directly in the field, made available on the ground in rows and in some situations used in the form of direct browsing. In addition to the points already discussed, legumes can also be used in the construction of small installations and energy generation due to the potential of their wood [10]. This diversification of forage resources within the production system reduces the need to import feed from other regions, and this is especially important in small properties where resources are scarcer.

Another key management practice to enhance cactus productivity is fertilizer application. Harvesting cactus removes a large amount of nutrients that must be replaced in order to keep the productivity and avoid depletion in soil fertility [11]. Organic fertilizers such as animal manure (e.g., goat, sheep, pig, cattle) have different nutrient releasing rates and are affected by the environment. In addition, it might contribute to improve soil physical, chemical, and biological characteristics. The choice of the best manure application rate varies with environmental conditions and plant population density. Silva et al. [12] observed positive linear response of cactus biomass to cattle manure up to $80 \mathrm{t} \mathrm{ha}^{-1}$ when cactus was densely planted $\left(160,000\right.$ plants ha $\left.{ }^{-1}\right)$, resulting in a biennial productivity of 139 t DM ha $^{-1}$.

Manure from different animal species have contrasting chemical composition and might result in different decomposition rates [13]. Our hypothesis is that the decomposition rate of different manures will vary, with faster rates observed in manures with lesser $\mathrm{C} / \mathrm{N}$ ratio, consequently leading to a greater nutrient accumulation in cactus amended with these manure types. Understanding the dynamics of mineralization from different sources of organic fertilizer in cactus cropping systems is essential for efficient management practices aiming the synchronism between nutrient release by manure and nutrient uptake by plants. Thus, the objective was to evaluate the release of nutrients from different manure types and the nutrient accumulation in forage cactus across different cropping systems.

\section{Materials and Methods}

\subsection{Site Description}

The study was conducted at the Experimental Station of Caruaru, which belongs to the Agronomic Institute of Pernambuco, IPA $\left(8^{\circ} 14^{\prime} \mathrm{S}\right.$ and $\left.35^{\circ} 55^{\prime} \mathrm{W}\right)$. The predominant soil in the experimental area is Regosol [14], and its chemical characteristics are on Table 1. The climate of the site is dry and hot semiarid, classified as BSh according to Köppen, with a rainfall volume and average temperature of $727 \mathrm{~mm}$ /year and $28^{\circ} \mathrm{C}$, respectively. Figure 1 shows the monthly rainfall data during the experimental period $(356 \mathrm{~mm})$.

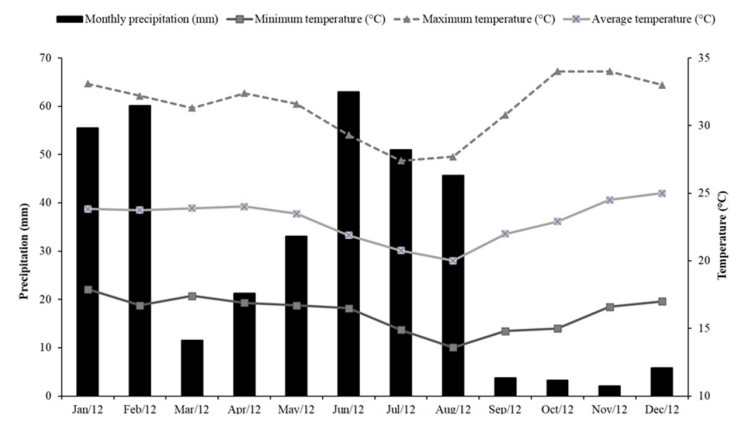

Figure 1. Meteorological variables during the experimental period in areas cultivated with forage cactus in Caruaru, PE. Arrows indicate the beginning and end of the trial period. Source: Agronomic Institute of Pernambuco-IPA (2013). 
Table 1. Soil physical and chemical characteristics in the experimental area at different soil layers.

\begin{tabular}{cccc}
\hline \multirow{2}{*}{ Attributes } & \multicolumn{3}{c}{ Soil Layer $(\mathbf{m})$} \\
\cline { 2 - 4 } & $\mathbf{0 - 0 . 1 0}$ & $\mathbf{0 - 0 . 2 0}$ & $\mathbf{0 . 2 0 - 0 . 4 0}$ \\
\hline Sand $\left(\mathrm{g} \mathrm{kg}^{-1}\right)^{1}$ & 746 & 748 & - \\
Silt $\left(\mathrm{g} \mathrm{kg}^{-1}\right)^{1}$ & 146 & 136 & - \\
${\text { Clay }\left(\mathrm{g} \mathrm{kg}^{-1}\right)^{1}}_{\text {Textural class }}$ & 108 & 116 & \\
$\mathrm{pH}\left(\mathrm{H}_{2} \mathrm{O}\right)^{2}$ & & Sandy & 4.7 \\
$\mathrm{P}\left(\mathrm{mg} / \mathrm{dm}^{3}\right)^{2}$ & 4.8 & 4.7 & 6.2 \\
$\mathrm{Ca}\left(\mathrm{cmolc} / \mathrm{dm}^{3}\right)^{2}$ & 23.5 & 15.5 & 1.61 \\
$\mathrm{Mg}\left(\mathrm{cmolc} / \mathrm{dm}^{3}\right)^{2}$ & 1.93 & 1.76 & 0.34 \\
$\mathrm{Na}\left(\mathrm{cmolc} / \mathrm{dm}^{3}\right)^{2}$ & 0.39 & 0.45 & 0.9 \\
$\mathrm{~K}\left(\mathrm{cmolc} / \mathrm{dm}^{3}\right)^{2}$ & 0.8 & 0.7 & 0.1 \\
$\mathrm{Al}\left(\mathrm{cmolc} / \mathrm{dm}^{3}\right)^{2}$ & 0.2 & 0.1 & 0.31 \\
$\mathrm{Al}+\mathrm{H}\left(\mathrm{cmolc} / \mathrm{dm}^{3}\right)^{2}$ & 0.27 & 0.28 & 2.29 \\
$\mathrm{TOC}\left(\mathrm{g} \cdot \mathrm{kg}^{-1}\right)^{2}$ & 2.38 & 2.32 & 8.91 \\
$\mathrm{SOM}\left(\mathrm{g} \cdot \mathrm{kg}^{-1}\right)$ & 9.59 & 8.75 & 15.7 \\
\hline
\end{tabular}

${ }^{1}[15]{ }^{2}$ [16]; TOC: total organic carbon; SOM: soil organic matter.

The experiment was implemented in March 2011. The natural vegetation in the experimental area was the Caatinga, which is native to the region. Legumes were planted in three double rows spaced $9 \times 1 \times 0.5 \mathrm{~m}$ apart. The planting of the IPA-Sertânia cactus was between double rows in monoculture at a spacing of $1 \times 0.25 \mathrm{~m}$ (Figure 2). In intercropped plots, the density of legumes was 4000 plants/ha and the density of cactus was 32,000 plants/ha, while in isolated cactus cultivation the density was 40,000 plants/ha. In February 2012, the experimental area was fertilized with different manures aiming to supply $200 \mathrm{~kg} \mathrm{~N} \mathrm{ha}^{-1}$ based on their respective $\mathrm{N}$ concentration (Table 2).
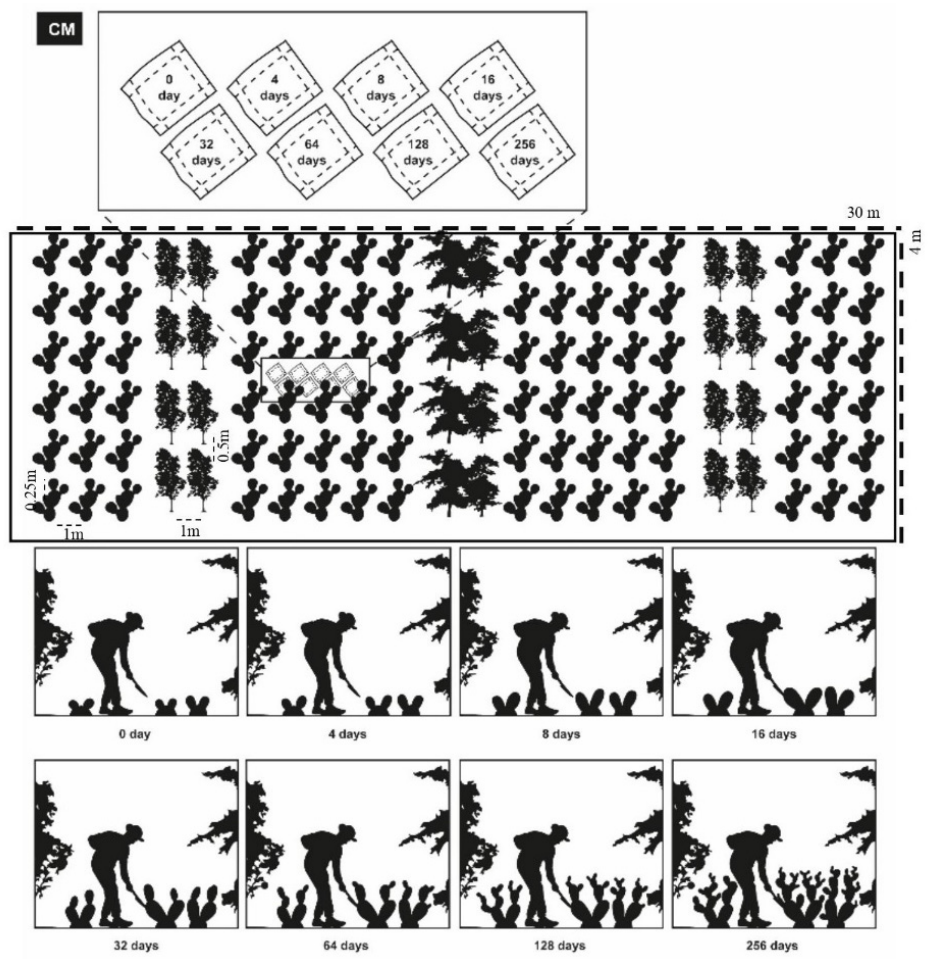

Figure 2. Schematic figure showing parallel retrieval of bags and sampling of cactus to assess manure disappearance and nutrient accumulation in aboveground cactus biomass. 
Table 2. Chemical characterization of different manure sources.

\begin{tabular}{|c|c|c|c|c|c|c|c|c|}
\hline \multirow{2}{*}{ Manure } & $\mathbf{N}$ & $\mathbf{P}$ & $\mathbf{K}$ & C & $\mathrm{C} / \mathrm{N}$ & $\mathrm{C} / \mathrm{P}$ & $\mathrm{C} / \mathrm{K}$ & OM \\
\hline & & $\mathrm{g} \mathrm{kg}^{-1}$ & & & & & & $\mathrm{~g} \mathrm{~kg}^{-1}$ \\
\hline Cattle & 11 & 6 & 142 & 232 & 21 & 39 & 2 & 400 \\
\hline Goat & 16 & 5 & 107 & 290 & 18 & 58 & 3 & 500 \\
\hline Sheep & 20 & 5 & 157 & 348 & 17 & 70 & 2 & 600 \\
\hline Broiler litter & 35 & 31 & 173 & 522 & 15 & 17 & 3 & 900 \\
\hline
\end{tabular}

OM: organic matter.

\subsection{Experimental Design}

Treatments consisted of different cropping systems (IPA-Sertânia Cactus + Leucaena, IPA-Sertânia Cactus + Gliricidia, and IPA-Sertânia Cactus in monoculture) and different sources of manure (cattle, goat, sheep, and broiler litter). Treatments were allocated in a randomized block in a split-plot design and four replications. The main plot $(30 \mathrm{~m} \times 16 \mathrm{~m})$ was the different cropping system, and the sub-plot $(30 \mathrm{~m} \times 4 \mathrm{~m})$ was the manure type.

\subsection{Sample Preparation and Analysis}

The decomposition and the release of nutrients from the different manures were estimated using the decomposition bag method or the litterbag method. Organic fertilizers were dried in an oven $\left( \pm 65^{\circ} \mathrm{C}\right)$ until constant weight, and then weighed and packed in $15 \times 30$-cm nylon bags with a $75-\mu \mathrm{m}$ mesh opening. Each bag received $20 \mathrm{~g}$ DM of pre-dried manure. This quantity of manure per bag was established according to the proportion of $22.5 \mathrm{mg}$ of manure per $\mathrm{cm}^{2}$ of bag considering both sides. The incubated manure was not ground; therefore, the particle size represented the manure used in field as close as possible, preserving the original surface from exposure to attacks by microorganisms [17].

The bags were placed in each subplot, covered with a thin layer of soil, and removed according to incubation periods $(0,4,8,16,32,64,128$, and 256 days) (Figure 2). In each incubation period, a bag was collected from the different sources of manure in each cropping system, totaling 48 bags per period. In the laboratory, the bags were opened. The organic residue contained in them was cleaned with a brush to remove soil residues and dried in an oven $\left( \pm 55^{\circ} \mathrm{C}\right)$ until constant weight. The mass was determined to assess the manure disappearance over time for each evaluation period. Samples were analyzed for DM, N, P, K, and C concentrations [18]. Organic matter was determined through loss on ignition, total nitrogen was obtained by the Kjeldhal method, and $\mathrm{P}$ and $\mathrm{K}$ were determined using Mehlich-1 extractant followed by reading in a spectrophotometer, and C was determined via oxidation with potassium dichromate [19].

The percentage of nutrients remaining on a given date was calculated based on the contents of each nutrient on that date and the contents on day zero. The percentage of biomass loss based on organic matter and the percentage of remaining nutrients were described using the negative single exponential model [20], described by the equation: $X=B 0 \mathrm{e}^{-\mathrm{kt}}$, where $\mathrm{X}=$ proportion of biomass (or nutrient) remaining in $\mathrm{T}$ days, $\mathrm{B} 0=$ disappearance constant, and $\mathrm{k}=$ relative decomposition rate.

Nutrient accumulation in cactus aboveground biomass was determined by harvesting two competitive plants from each subplot, in each evaluated incubation period $(0,4,8,16$, $32,64,128$, and 256 days) preserving the mother cladode (Figure 2). The collected plants were weighed and dried in an oven at $65{ }^{\circ} \mathrm{C}$ until constant weight, and then ground at 1 $\mathrm{mm}$. Cladode concentrations of $\mathrm{N}, \mathrm{P}$, and $\mathrm{K}$ were then determined by the same methods described for the manure.

The amount of nutrient released in the manure was estimated as a function of the remaining amount of manure in the different incubation periods and the concentration of $\mathrm{N}, \mathrm{P}$ and $\mathrm{K}$ in each period evaluated $(0,4,8,16,32,64,128$ and 256 days). For plant 
accumulation, the forage production in the cactus plant population was considered, as well as the amount of N, P and $\mathrm{K}$ in each period studied.

\subsection{Statistical Analysis}

The data were analyzed using the Proc mixed procedure of SAS/STAT ${ }^{\circledR} 14.1$ (Cary, NC, USA) [21]. The blocks were considered random effect. The fixed effects included cropping systems, manure sources, and evaluation dates, which were considered the repeated measure. The means (LSMEANS) were compared by PDIFF adjusted for Tukey $(p<0.05)$. Data was analyzed as split plot.

\section{Results}

\subsection{Manure Decomposition}

Manure remaining biomass changed over time $(p<0.01)$ in response to different manure sources and incubation periods (Figure 3 ). In the initial incubation periods ( 0 to 16 days), the decomposition rate was similar among the different sources of manure. After 256 days of incubation, the remaining biomass was $98,90,88$, and $57 \%$ for goat, cattle, sheep manure, and broiler litter, respectively. Goat manure had the least decomposition (i.e., greatest amount of remaining biomass in the bag). Concentrations of $\mathrm{N}, \mathrm{P}$, and $\mathrm{K}$ varied along the evaluation period for the different manure types (Figure 4). However, there was an increase in the concentrations of $\mathrm{N}$ (16 days), $\mathrm{P}$ (4 days), and $\mathrm{K}$ (32 days) in the forage cactus, which then decreased later (Figure $4 \mathrm{~A}$ ).

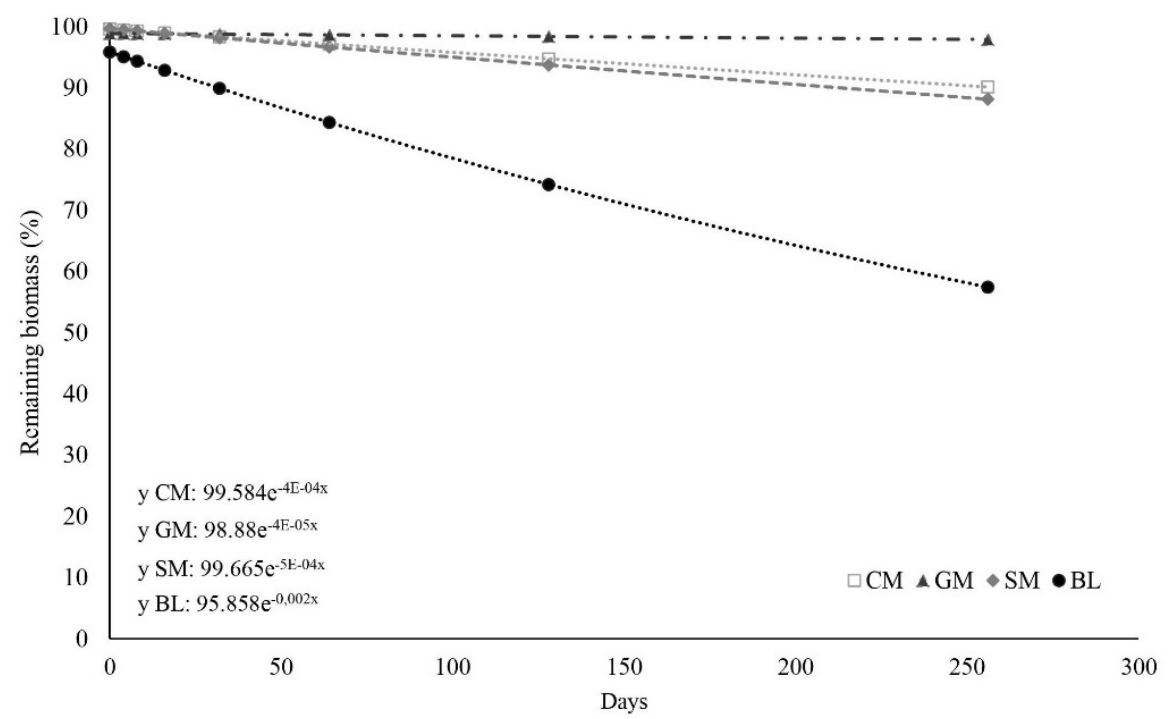

Figure 3. Remaining biomass from different manures in different forage cactus cropping systems. CM: Cattle manure; GM: Goat manure; SM: Sheep manure; BL: Broiler litter.
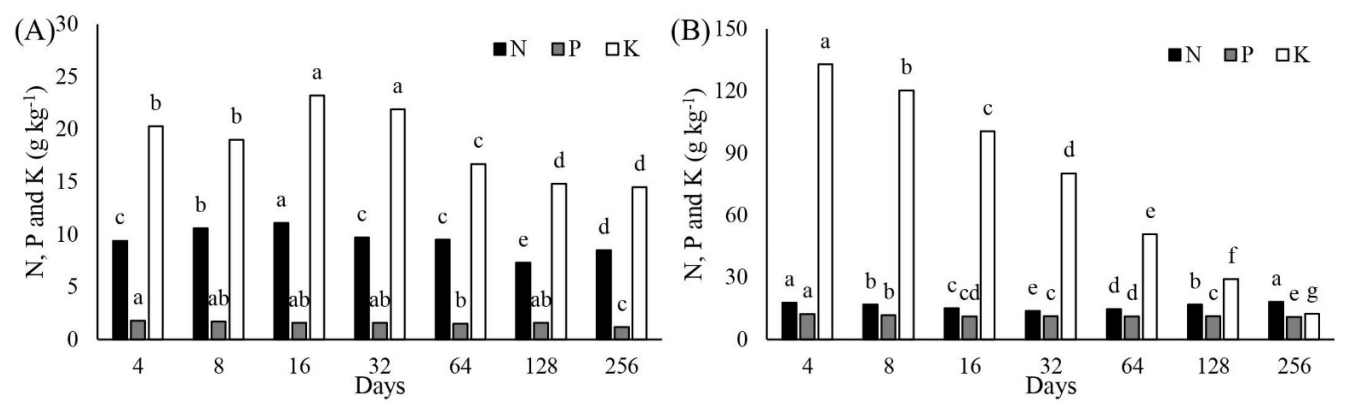

Figure 4. Concentrations of N, P, and K in the IPA-Sertânia cactus aboveground biomass (A) and manure (B). Different small letters indicate significant difference $(p<0.05)$ within each nutrient by PDIFF adjusted to Tukey. 


\subsection{Nitrogen Accumulation in Aboveground Cactus Biomass and Release from Manure}

The rate of $\mathrm{N}$ accumulation by aboveground cactus biomass and manure release was significantly affected by cropping system, manure source, and incubation periods (Figure 5). Cactus accumulated more $\mathrm{N}$ in aboveground biomass when intercropped with Gliricidia, regardless of manure source, with means of $0.91,0.59,0.55$, and $0.50 \mathrm{~kg} \mathrm{~N}^{-1}$ $\mathrm{day}^{-1}$ for broiler, sheep, cattle, and goat manure, respectively, at 256 days. The greatest $\mathrm{N}$ release occurred from broiler litter $\left(56 \mathrm{~kg} \mathrm{~N} \mathrm{ha}^{-1}\right)$ and sheep manure $\left(25 \mathrm{~kg} \mathrm{~N} \mathrm{ha}^{-1}\right)$ at 256 days. Nitrogen disappearance from goat and cattle manures decreased after 64 days of incubation, showing a release rate of approximately $45 \%$ of the initial $\mathrm{N}$.

The intercropping of cactus with Leucaena showed a similar behavior as that observed in the intercropping with Gliricidia, i.e., an increase in the $\mathrm{N}$ accumulation over the incubation time. Broiler litter and goat manure provided the greatest $\mathrm{N}$ accumulations ( 0.79 and $0.63 \mathrm{~kg} \mathrm{~N} \mathrm{ha}^{-1} \mathrm{day}^{-1}$ ) after 256 days, respectively (Figure 5).

Cactus grown in monocultures had the least $\mathrm{N}$ accumulation compared to the intercropped systems. Broiler litter and goat manure provided the greatest $\mathrm{N}$ accumulations in this system $\left(0.78\right.$ and $\left.0.61 \mathrm{~kg} \mathrm{~N} \mathrm{ha}^{-1} \mathrm{day}^{-1}\right)$ at $\mathrm{d} 256$, respectively (Figure 5). The greatest $\mathrm{N}$ release occurred in broiler litter and sheep manure at 256 days.

\subsection{Phosphorus Accumulation in Cactus Aboveground Biomass and Release from Manure}

Phosphorus accumulation rate in cactus aboveground biomass and $\mathrm{P}$ release rate were significantly $(p<0.05)$ affected by cropping system, manure source, and incubation period (Figure 6). In the cactus intercropped with Gliricidia, cattle manure provided the greatest accumulation of $\mathrm{P}\left(0.09 \mathrm{~kg} \mathrm{P} \mathrm{ha}^{-1} \mathrm{day}^{-1}\right)$ in $\mathrm{d} 256$. Forage cactus had the maximum accumulation of $\mathrm{P}\left(41 \mathrm{~kg} \mathrm{P} \mathrm{ha}^{-1}\right)$ at 256 days. Broiler litter $\left(48 \mathrm{~kg} \mathrm{P} \mathrm{ha}^{-1}\right)$ and cattle manure $\left(14 \mathrm{~kg} \mathrm{P} \mathrm{ha}^{-1}\right)$ released more $\mathrm{P}$ than other manure types.

Cactus intercropped with Leucaena had a similar $\mathrm{P}$ accumulation rate as that of the intercropping with Gliricidia (Figure 6). Cattle manure provided the greatest $P$ accumulation $\left(0.13 \mathrm{~kg} \mathrm{P} \mathrm{ha}^{-1} \mathrm{day}^{-1}\right)$. Goat and sheep manures had an intermediate accumulation $\left(0.12\right.$ and $0.12 \mathrm{~kg} \mathrm{P} \mathrm{ha}^{-1}$ day $\left.^{-1}\right)$ in $\mathrm{d} 256$, respectively. The greatest $\mathrm{P}$ release occurred from broiler litter $\left(321 \mathrm{~kg} \mathrm{P} \mathrm{ha}^{-1}\right)$.

Cactus grown in monoculture accumulated less $\mathrm{P}$ compared when grown in intercropped systems (Figure 6). Goat manure provided the greatest $P$ accumulation $(0.11 \mathrm{~kg}$ $\mathrm{P} \mathrm{ha}^{-1}$ day $^{-1}$ ). The least accumulation occurred in cactus fertilized with sheep manure $\left(0.01 \mathrm{~kg} \mathrm{P} \mathrm{ha}^{-1} \mathrm{day}^{-1}\right)$. The greatest $\mathrm{P}$ release occurred from broiler litter $\left(133 \mathrm{~kg} \mathrm{P} \mathrm{ha}^{-1}\right)$ and sheep manure $\left(11 \mathrm{~kg} \mathrm{P} \mathrm{ha}^{-1}\right)$.

\subsection{Potassium Accumulation Rate in Cactus Aboveground Biomass and K Release from Manure}

The $\mathrm{K}$ accumulation rate in cactus aboveground biomass and the $\mathrm{K}$ release rate from manure were significantly $(p<0.05)$ affected by different cropping system, manure source, and incubation period (Figure 7). When forage cactus was intercropped with Gliricidia, cattle manure $\left(1.18 \mathrm{~kg} \mathrm{~K} \mathrm{ha}^{-1}\right.$ day $\left.^{-1}\right)$ provided the greatest $\mathrm{K}$ accumulation. The greatest release occurred in sheep manure $\left(81 \mathrm{~kg} \mathrm{~K} \mathrm{ha}^{-1}\right)$ and cattle manure $\left(45 \mathrm{~kg} \mathrm{~K} \mathrm{ha}^{-1}\right)$ in d 256.

For cactus intercropped with Leucaena (Figure 7), sheep manure promoted the greatest accumulation and release of $\mathrm{K}\left(1.42 \mathrm{~kg} \mathrm{~K} \mathrm{ha}^{-1}\right.$ day $^{-1}$ and $15 \mathrm{~kg} \mathrm{~K} \mathrm{ha}^{-1}$ at d 256, respectively). The least accumulation occurred when cattle manure was applied $\left(0.70 \mathrm{~kg} \mathrm{~K} \mathrm{ha}^{-1}\right.$ day $\left.^{-1}\right)$. For cactus in monoculture, broiler litter provided the greatest $\mathrm{K}$ accumulation $\left(1.23 \mathrm{~kg} \mathrm{ha}^{-1} \mathrm{day}^{-1}\right)$. The $\mathrm{K}$ release rate was similar as that observed in intercropped systems. The greatest $\mathrm{K}$ release occurred from sheep manure $\left(64 \mathrm{~kg} \mathrm{~K} \mathrm{ha}^{-1}\right)$ at $\mathrm{d} 256$. 

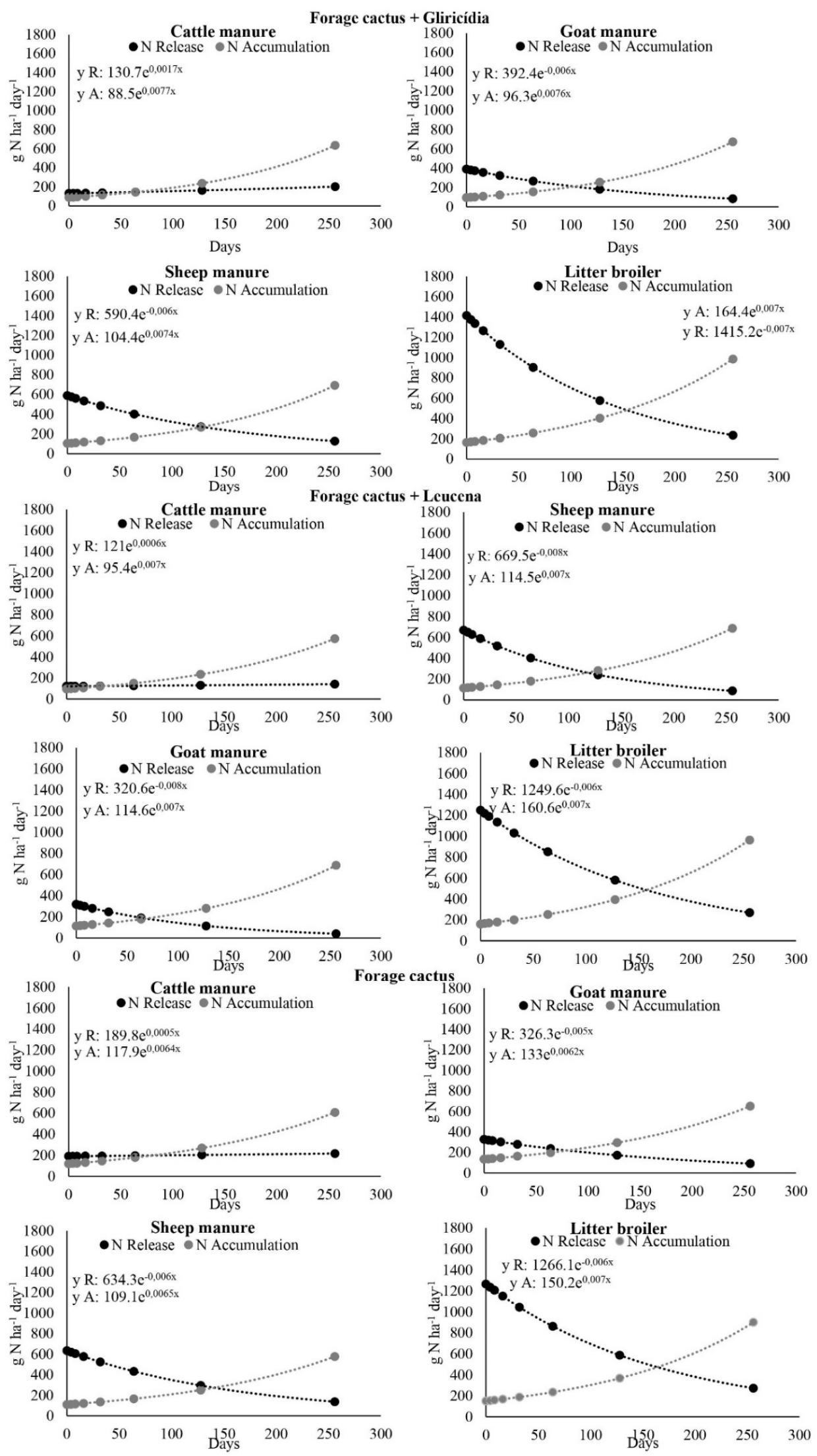

Figure 5. Rate of $\mathrm{N}$ accumulation by cactus and release from different manure sources in different forage cactus cropping systems. 

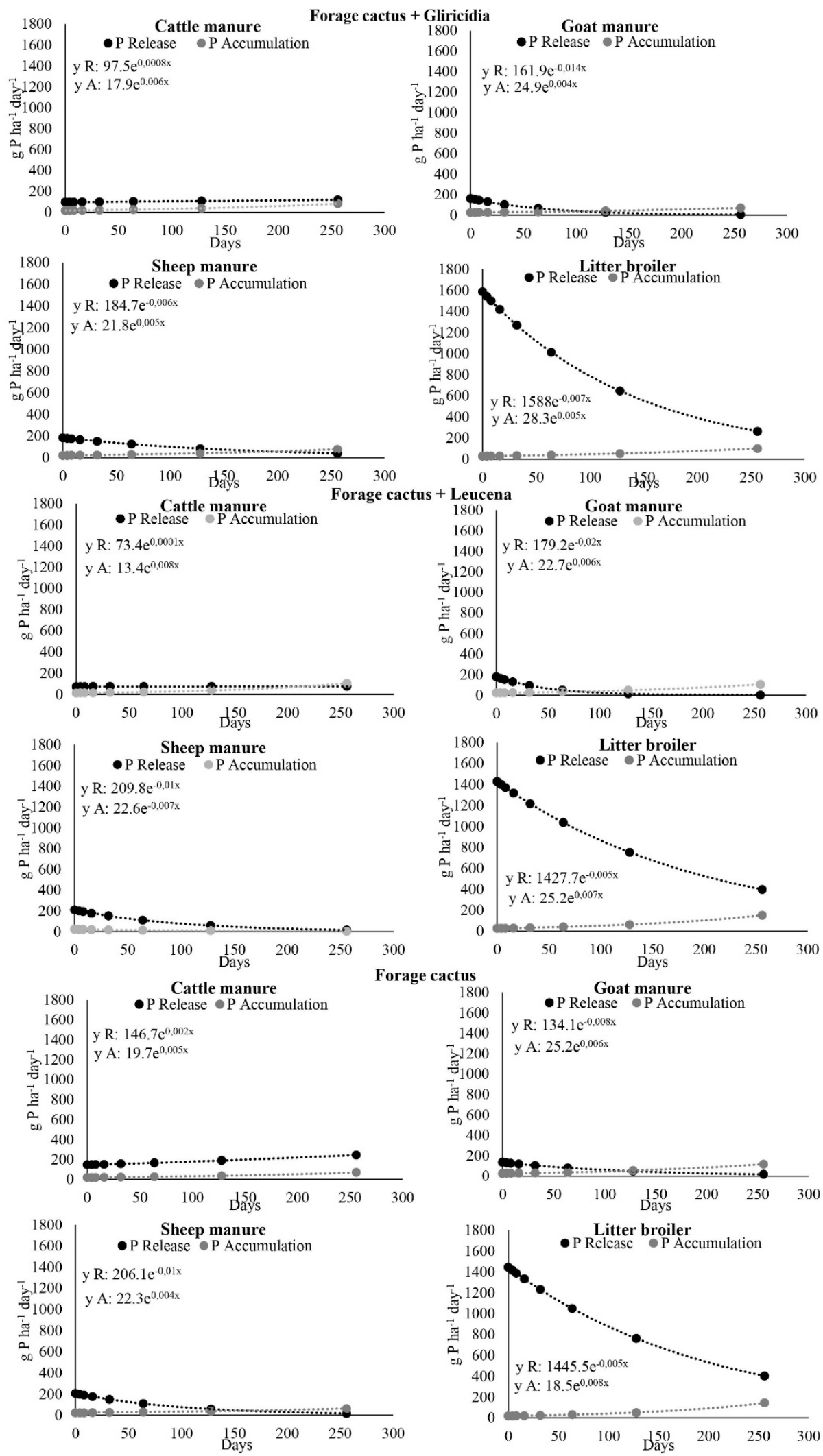

Figure 6. Rate of $\mathrm{P}$ accumulation in cactus aboveground biomass and $\mathrm{P}$ release from different manure types in a variety of forage cactus cropping systems. 

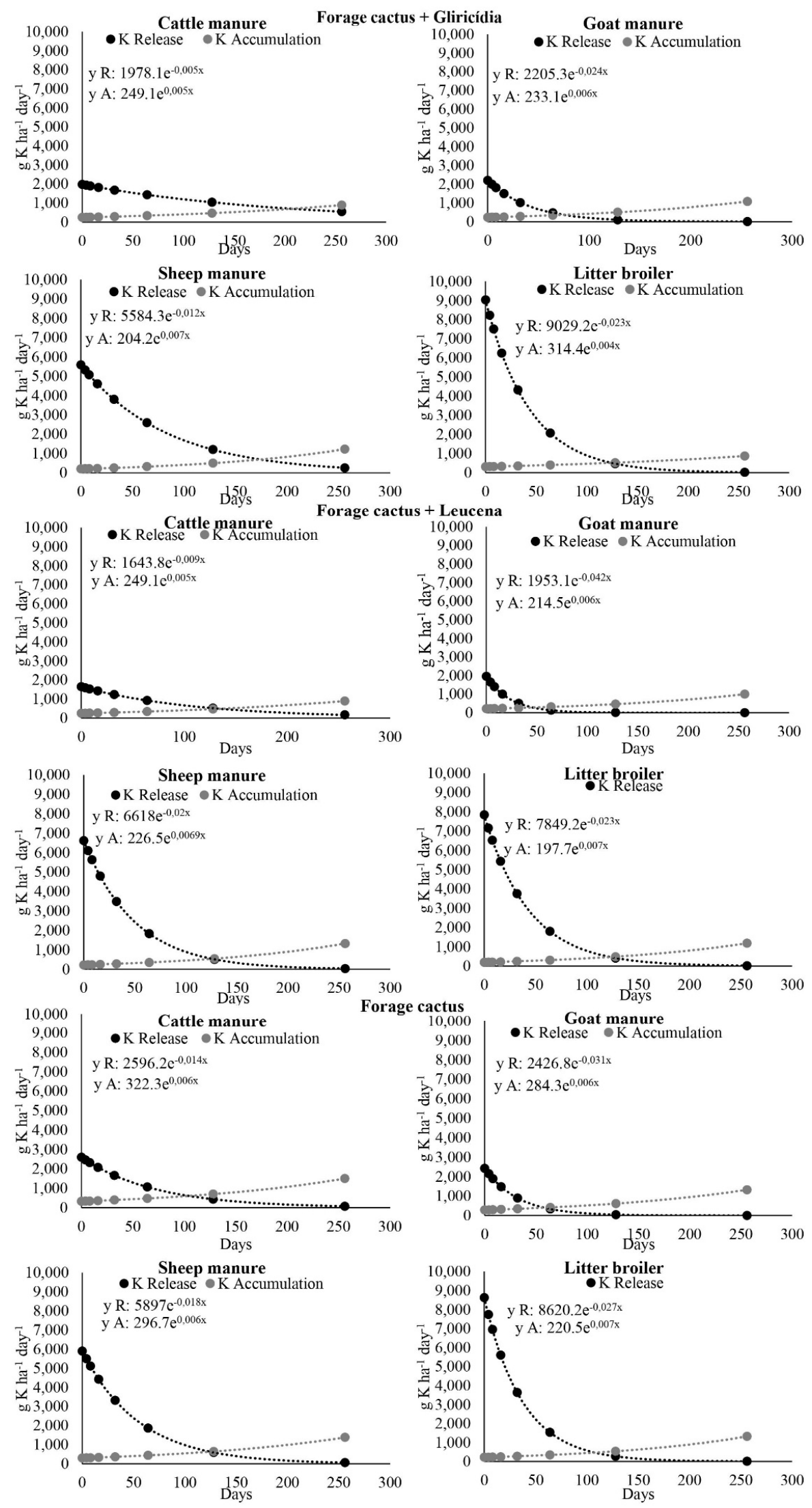

Figure 7. Rate of $\mathrm{K}$ accumulation in cactus aboveground biomass and $\mathrm{K}$ release from different manure types in a variety of forage cactus cropping systems. 


\section{Discussion}

Nutrient ( $\mathrm{N}$ and $\mathrm{K}$ ) accumulation over time in cactus aboveground biomass and the concomitant release of these nutrients from manures (Figure 4) indicate a synchronism. The rapid $\mathrm{P}$ disappearance from manures and its steady content in cactus might have occurred because of the soil P dynamics forming stable complexes with amorphous minerals of Fe and $\mathrm{Al}$ or lost via leaching [22,23]. Nobile et al. [24] indicated that the application of organic fertilizer may improve the availability of soil $\mathrm{P}$ compared to the application of chemical fertilizer.

The slower initial manure decomposition (Figure 3) can be attributed to the atypical rainfall conditions in 2012 with only $360 \mathrm{~mm}$ of annual rainfall (Figure 1). Water is essential for the maintenance of microbial activity and decomposition of organic residues because it participates in chemical reactions, diffusion of nutrients, and microbial motility [25]. Another factor that may have contributed to such a slow decomposition is the absence of actions by the macrofauna $(>2.0 \mathrm{~mm})$ and the mesofauna $(0.2-2.0 \mathrm{~mm})$ inside the litter bags [26]. Such actions break down organic residues and enhances decomposition [27], however, because of the low porosity of the mesh of nylon bags $(75 \mu \mathrm{m})$ they likely occurred at a lesser extent.

In the different cropping systems, broiler litter showed the greatest release rates for $\mathrm{N}$ and $\mathrm{P}$ (Figure 3 ) and the greatest rates of $\mathrm{N}$ accumulation in aboveground cactus biomass (Figure 5, Figure 6, Figure 7). These results may be related to the greatest levels of $\mathrm{N}$, $\mathrm{P}, \mathrm{K}$, and the least $\mathrm{C} / \mathrm{N}$ ratio (Table 2) found in broiler litter [28]. Decomposition rate is determined by the quality of organic residues, so that residues with lesser values of $\mathrm{C} / \mathrm{N}$, lignin/N, and polyphenols/ $\mathrm{N}$ ratios decompose more quickly [27,29].

This result corroborates the study of Silva et al. [28], who observed that broiler litter decomposed faster, releasing more $\mathrm{N}$ and $\mathrm{K}$ than cattle manure. The authors attribute this to frequent microbial attacks to the fractions of broiler litter, as fractions present a greater proportion of easily biodegradable $C$ forms of easier and faster decomposition (e.g., sugars, amino acids, proteins). Broiler litter also has lesser concentration of more complex organic compounds that undergo slower decomposition (e.g., cellulose, lignin, fats). Miranda et al. [1] also observed greater $\mathrm{N}$ concentrations in IPA-Sertânia cactus fertilized with broiler litter compared to ruminant (cattle, sheep, goat) manure.

The least $\mathrm{N}$ accumulation in cactus growing in monoculture (Figure 5) is probably related to the absence of biological $\mathrm{N}_{2}$ fixation (BNF) performed by diazotrophic bacteria in symbiosis with legumes [30]. Legumes that were grown in intercropping systems are known for their $\mathrm{N}$ contribution to the soil. According to Apolinário et al. [31], Gliricidia may add up to $110 \mathrm{~kg} \mathrm{~N} \mathrm{ha}^{-1}$ year $^{-1}$ via BNF. Leucaena can fix up to $80 \mathrm{~kg} \mathrm{~N} \mathrm{ha}^{-1}$ in 100 days [32]. It is worth noting that the less accumulation of $0.59 \mathrm{~kg} \mathrm{~N} \mathrm{ha}^{-1} \mathrm{day}^{-1}$ in cactus monoculture (Figure 5) is probably a result of lesser $\mathrm{N}$ inputs due to the lack of tree legumes in that system.

According to Donato et al. [33], in order to produce $21.8 \mathrm{Mg} \mathrm{DM} \mathrm{ha}^{-1} \mathrm{year}^{-1}$ of forage cactus, the requirement is 288,46 , and $924 \mathrm{~kg} \mathrm{~N}, \mathrm{P}$, and $\mathrm{K} \mathrm{ha}^{-1}$ year ${ }^{-1}$, respectively. In a forage cactus system intercropped with Leucaena and fertilized with broiler litter, there were probably adequate levels of $\mathrm{N}$ and $\mathrm{P}$ (423 and $457 \mathrm{~kg} \mathrm{ha}^{-1}$ year ${ }^{-1}$, respectively). This manure source released the largest amounts of $\mathrm{N}$ and $\mathrm{P}$, an average of 227 and $239 \mathrm{~kg}$ $\mathrm{ha}^{-1}$ year $^{-1}$, respectively (Figures 5 and 6 ). Regarding the $\mathrm{K}$ accumulation in aboveground cactus biomass, none of the sources met the requirements of forage cactus. However, there was a greater release of $\mathrm{K}$ by sheep manure $\left(76 \mathrm{~kg} \mathrm{~K} \mathrm{ha}^{-1}\right.$ year $\left.{ }^{-1}\right)$ compared with other sources. Goat manure released the least amounts of N, P, and K: 18, 5, and $15 \mathrm{~kg} \mathrm{ha}^{-1}$ year $^{-1}$, respectively.

The greatest $\mathrm{N}$ release and accumulation of $\mathrm{N}$ in aboveground cactus biomass occurred with broiler litter (Figure 5). Some synchronism occurred between nutrient release from manure and accumulation in cactus biomass, however, for all manure types there were times when nutrient accumulation surpassed nutrient release from manure, especially for $\mathrm{N}$ and K. For P accumulation, manures generally supplied enough P. It is important to note 
that despite the greatest $P$ release has occurred in broiler litter, the greatest accumulation occurred in plots fertilized with cattle manure. This can be explained by potential P losses. Thus, Oladipupo et al. [34] recommend mixing broiler litter with other manure (cattle and goat) due to its complementary and its synergistic effect.

Donato et al. [35] demonstrated that the contents of $\mathrm{K}$ in the Gigante cactus increase as the doses of cattle manure increase $\left(0,30,60\right.$, and $90 \mathrm{Mg} \mathrm{ha}^{-1}$ year $\left.{ }^{-1}\right)$. Thus, in order to meet cactus $\mathrm{K}$ requirements, a dose greater than $200 \mathrm{~kg} \mathrm{~N} \mathrm{ha}^{-1}$ is necessary when using similar manure types as the ones used in this study. Lédo et al. [36] observed that organic-mineral fertilization of Gigante cactus promoted greater concentrations of K (39 to $44 \mathrm{~g} \mathrm{~kg}^{-1}$ ) when compared with chemical and organic fertilization.

The slow release and accumulation of $\mathrm{N}, \mathrm{P}$, and $\mathrm{K}$ in cactus aboveground biomass when using goat manure (Figure 7 ) might be related to a greater $\mathrm{C} / \mathrm{N}$ ratio in this manure type. Manure chemical composition is closely related to the diets of animals [37]. Goats are more selective animals, and they tend to have an excrement with greater $\mathrm{N}$ concentration, however, the physical form of goat feces makes them more difficult for microbial attack [13].

\section{Conclusions}

Broiler litter decomposes faster than other manure types, releasing the greatest amounts of $\mathrm{N}$ and $\mathrm{P}$. However, sheep manure provided the greatest $\mathrm{K}$ accumulation in the aboveground cactus biomass. Broiler litter, cattle manure, and sheep manure favors the greatest accumulations of $\mathrm{N}, \mathrm{P}$, and $\mathrm{K}$, respectively.

Manure in general provided enough $\mathrm{P}$ for cactus growth, however, $\mathrm{N}$ and $\mathrm{K}$ supply released from manure only met initial cactus demand, with rate of nutrient accumulation surpassing the rate of nutrient release after 100 days in most of the cases. Broiler litter released greater amounts of nutrients earlier in the growth curve, but that might have led to nutrient losses not helping nutrient accumulation in cactus biomass. Combination of organic and inorganic sources of fertilizer or even combination of manure types might be one of the options to match nutrient release curve with crop needs.

The use of legumes in the system might have increased nutrient supply through biological fixation and litter decomposition, helping to supply nutrients to the intercropped cactus.

Author Contributions: Conceptualization, J.C.B.D.J. and F.M.S.; methodology, J.C.B.D.J., R.S.C.M., M.V.F.d.S., M.V.d.C.; software, J.C.B.D.J., F.M.S.; validation, F.M.S., I.F.; formal analysis, J.C.B.D.J., F.M.S.; investigation, F.M.S., I.F., J.C.B.D.J.; resources, J.C.B.D.J., M.V.F.d.S., I.F.; data curation, F.M.S.; writing—original draft preparation, F.M.S., J.C.B.D.J.; writing—review and editing, F.M.S., J.C.B.D.J., D.C.; visualization, F.M.S., J.C.B.D.J., D.C.; supervision, J.C.B.D.J.; project administration, J.C.B.D.J., I.F., M.V.F.d.S.; funding acquisition, J.C.B.D.J. All authors have read and agreed to the published version of the manuscript.

Funding: This research was partial funded by CAPES (financial code 001).

Institutional Review Board Statement: Not applicable.

Informed Consent Statement: Not applicable.

Data Availability Statement: Data is available per request and is stored by F.M.S.

Acknowledgments: The author F.M.S. thanks to Fundação de Amparo a Ciência e Tecnologia do Estado de Pernambuco (FACEPE, Brazil), and the authors M.V.F.S., R.S.C.M., and D.C. thank to Conselho Nacional de Desenvolvimento Científico e Tecnológico (CNPq, Brazil) for the fellowship granted and financial support. All authors thank CAPES (financial code 001) for the partial funding of this study.

Conflicts of Interest: The authors declare no conflict of interest. 


\section{References}

1. Miranda, K.R.D.; Dubeux Júnior, J.C.B.; Mello, A.C.L.; Silva, M.C.; Santos, M.V.F.; Santos, D.C. Forage Production and Mineral Composition of Cactus Intercropped with Legumes and Fertilized with Different Sources of Manure. Ciência Rural. 2019, 49, e20180324. [CrossRef]

2. Castro, I.N.; Santos, S.R.; Kondo, M.K.; Maia, V.; Santos, C.C.R. Agronomic Performance and Water Use Efficiency of Irrigated Cactus Pear Cultivars. Rev. Caatinga 2020, 33, 529-540. [CrossRef]

3. Souza, T.C.; Santos, M.V.F.; Dubeux Júnior, J.C.B.; Lira, M.A.; Santos, D.C.; Cunha, M.V.; Silva, R.R. Productivity and Nutrient Concentration in Spineless Cactus Under Different Fertilizations and Plant Densities. Rev. Bras. De Ciências Agrárias 2017, 12, 555-560. [CrossRef]

4. Vasconcelos, A.G.V.; Lira, M.A.; Cavalcanti, V.L.B.; Santos, M.V.F.; Willadino, L. Selection of Prickly-Pear Clones Resistant to Carmine Cochineal Dactylopius sp. Rev. Bras. De Zootec. 2009, 38, 827-831. [CrossRef]

5. Edvan, R.L.; Mota, R.R.M.; Silva, T.P.S.; Nascimento, R.R.; Sousa, S.V.; Silva, A.L.; Araújo, J.S. Resilience of Cactus Pear Genotypes in A Tropical Semi-Arid Region Subject to Climatic Cultivation Restriction. Sci. Rep. 2020, 10, 1-10. [CrossRef] [PubMed]

6. Mayer, J.A.; Cushman, J.C. Nutritional and Mineral Content of Prickly Pear Cactus: A Highly Water-Use Efficient Forage, Fodder and Food Species. J. Agron. Crop. Sci. 2019, 205, 625-634. [CrossRef]

7. Schumacher, M.V.; Szymczak, D.A.; Trüby, P.; Londero, E.K.; Marafiga, J. Litter and Nutrient Input in Seasonal Forest in The Central Region of Rio Grande do Sul state. Ciência Florest. 2018, 28, 532-541. [CrossRef]

8. Oli, P.S.; Mandal, T.N.; Adhikari, U. Effect of Leaf Litter Treatment on Soil Microbial Biomass. Open J. Soil Sci. 2018, 8, 175-185. [CrossRef]

9. Santos, F.M.S.C.; Lima Junior, D.M.; Cardoso, D.B.; Maciel, M.V.; Carvalho, F.F.R. Replacement of Tifton 85 Hay with Maniçoba Hay in The Spineless Cactus Diet of Sheep. Rev. Caatinga 2021, 1, 219-227. [CrossRef]

10. Silva, L.L.H.; Oliveira, E.; Calegari, L.; Pimenta, M.C.; Dantas, M.K.L. Características Dendrométricas, Físicas e Químicas da Myracrodruon Urundeuva e da Leucaena Leucocephala. Floresta e Ambiente 2017, 24, 1-8. [CrossRef]

11. Silva, J.A.D.; Donato, S.L.; Donato, P.E.; Souza, E.D.S.; Padilha Júnior, M.C.; Junior, S. Extraction/Export of Nutrients in Opuntia ficus-indica Under Different Spacings and Chemical Fertilizers. Rev. Bras. De Eng. Agrícola E Ambient. 2016, 20, 236-242. [CrossRef]

12. Silva, N.G.M.; Santos, M.V.F.; Dubeux Júnior, J.C.B.; Cunha, M.V.; Lira, M.A.; Ferraz, I. Effects of Planting Density and Organic Fertilization Doses on Productive Efficiency of Cactus Pear. Rev. Caatinga 2016, 29, 976-983. [CrossRef]

13. Zhu, Y.; Merbold, L.; Leitner, S.; Pelster, D.E.; Okoma, S.A.; Ngetich, F.; Butterbach-Bahl, K. The Effects of Climate on Decomposition of Cattle, Sheep and Goat Manure in Kenyan Tropical Pastures. Plant Soil 2020, 451, 325-343. [CrossRef]

14. Food and Agriculture Organization (FAO). World Reference Base for Soil Resources: International Soil Classification System for Naming Soils and Creating Legends for Soil Maps. World Soil Resour. Rep. 2014, 106, 192.

15. Almeida, B.G.; Donagemma, G.K.; Ruiz, H.A.; Braida, J.A.; Viana, J.H.M.; Reichert, J.M.M.; Passos, R.R. Standardization of Methods for Granulometric Analyses in Brazil. Embrapa Solos-Comun. Técnico 2012, 66, 11.

16. Empresa Brasileira de Pesquisa Agropecuária (EMBRAPA). Manual de métodos de análise de solo, 2nd ed.; Embrapa Solos: Rio de Janeiro, Brazil, 2011; 230p.

17. Dubeux Júnior, J.C.B.; Sollenberger, L.E.; Interrante, S.M.; Vendramini, J.M.B.; Stewart Jr, R.L. Litter Decomposition and Mineralization in Bahiagrass Pastures Managed at Different Intensities. Crop. Sci. 2006, 46, 1305-1310. [CrossRef]

18. Association of Official Analytical Chemists. Official Methods of Analysis, 18th ed.; AOAC: Arlington, TX, USA, 2005.

19. Silva, F.C. Manual de Análises Químicas de Solos, Plantas e Fertilizantes, 2nd ed.; Embrapa Solos: Rio de Janeiro, Brazil, 1999; pp. 171-223.

20. Wagner, G.H.; Wolf, D.C. Carbon Transformation and Soil Organic Matter Formations. In Principles and Applications of Soil Microbiology; Sylvia, D.M., Hartel, P.G., Fuhrmann, J.J., Zubere, D.A., Eds.; Prentice Hall: Englewood Cliffs, NJ, USA, 1999; pp. 218-258.

21. SAS Institute Inc. SAS/STAT®14.1 User's Guide; SAS Institute Inc.: Cary, NC, USA, 2015.

22. Yan, X.; Wei, Z.; Hong, Q.; Lu, Z.; Wu, J. Phosphorus Fractions and Sorption Characteristics in a Subtropical Paddy Soil as Influenced by Fertilizer Sources. Geoderma 2017, 295, 80-85. [CrossRef]

23. Fei, C.; Zhang, S.R.; Wei, W.L.; Liang, B.; Ding, X.D. Straw and Optimized Nitrogen Fertilizer Decreases Phosphorus Leaching Risks in a Long-Term Greenhouse Soil. J. Soils Sediments 2019, 20, 1199-1207. [CrossRef]

24. Nobile, C.; Bravin, M.N.; Becquer, T.; Paillat, J. Phosphorus Sorption and Availability in an Andosol After a Decade of Organic or Mineral Fertilizer Applications: Importance of $\mathrm{pH}$ and Organic Carbon Modifications in Soil as Compared to Phosphorus Accumulation. Chemosphere 2020, 239, 124709. [CrossRef]

25. Horwath, W.R. The Role of the Soil Microbial Biomass in Cycling Nutrients. Microb. Biomass: A Paradig. Shif Terr. Biogeochem. 2017, 41-66. [CrossRef]

26. Slade, E.M.; Riutta, T. Interacting Effects of Leaf Litter Species and Macrofauna on Decomposition in Different Litter Environments. Basic Appl. Ecol. 2012, 13, 423-431. [CrossRef]

27. Cardoso, E.J.B.N.; Andreote, F.D. Soil Microbiology, 2nd ed.; ESALQ: Piracicaba, Brazil, 2016.

28. Silva, V.B.; Silva, A.P.; Dias, B.O.; Araujo, J.L.; Santos, D.; Franco, R.P. Decomposition and Mineralization of N, P and K of Cattle Manure and Poultry Litter Isolated or Mixed. Rev. Bras. De Ciência Do Solo 2014, 38, 1537-1546. [CrossRef] 
29. Nguyen, X.P.; Jho, H.; Jeong, Y.J.; Jo, Y.T.; Islam, M.N.; Park, J.H. Characterization of Composted Chicken Manures Discharged from Farms in South Korea. Environ. Eng. Res. 2015, 20, 254-259. [CrossRef]

30. Barros, F.M.D.R.; Fracetto, G.G.M.; Fracetto, F.J.C.; Mendes Júnior, J.P.; Araújo, V.L.V.P.; Lira, M.A., Jr. Silvopastoral Systems Drive The Nitrogen Cycling Bacterial Community in Soil. Ciência E Agrotecnologia 2018, 42, 281-290. [CrossRef]

31. Apolinário, V.X.O.; Dubeux, J.C.B., Jr.; Lira, M.A.; Ferreira, R.L.C.; Mello, A.C.L.; Santos, M.V.F.; Sampaio, E.V.S.B.; Muir, J.P. Tree Legumes Provide Marketable Wood and add Nitrogen in Warm-Climate Silvopasture Systems. Agron. J. 2015, 107, 1915-1921. [CrossRef]

32. Sarabia-Salgado, L.; Solorio-Sánchez, F.; Ramírez-Avilés, L.; Alves, B.J.R.; Ku-Vera, J.; Aguilar-Pérez, C.; Boddey, R.M. Increase in Milk Yield from Cows Through Improvement of Forage Production using The $\mathrm{N}_{2}$-fixing Legume Leucaena leucocephala in a Silvopastoral System. Animals 2020, 10, 734. [CrossRef]

33. Donato, P.E.; Donato, S.L.; Silva, J.A.; Pires, A.J.; Junior, S. Extraction/Exportation of Macronutrients by Cladodes of 'Gigante'cactus Pear under Different Spacings and Organic Fertilization. Rev. Bras. De Eng. Agrícola E Ambient. 2017, 21, 238-243. [CrossRef]

34. Oladipupo, A.J.; Alade, A.A.; Adewuyi, S.; Ajiboye, G.A.; Blessing, O.T. Soil Phosphorus Fractions, Reaction, and Conductivity in Some Southwestern Nigerian Soils as Affected by Animal Manure Mixtures. Commun. Soil Sci. Plant Anal. 2020, 51, 2616-2632. [CrossRef]

35. Donato, P.E.; Donato, S.L.; Silva, J.A.; Pires, A.J.; Rosa, R.C.; Aquino, A.A. Nutrition and Yield of 'Gigante' Cactus Pear Cultivated with Different Spacings and Organic Fertilizer. Rev. Bras. De Eng. Agrícola E Ambient. 2016, 20, 1083-1088. [CrossRef]

36. Lédo, A.A.; Donato, S.L.; Aspiazu, I.; Silva, J.A.D.; Donato, P.E.; Carvalho, A.J.D. Nutrient Concentration and Nutritional Efficiency in 'Gigante' Cactus Pear Submitted to Different Spacings and Fertilizations. Rev. Bras. De Eng. Agrícola E Ambient. 2020, 24, 154-161. [CrossRef]

37. Somda, Z.C.; Powell, J.M. Seasonal Decomposition of Sheep Manure and Forage Leaves in Soil. Commun. Soil Sci. Plant Anal. 1998, 29, 2961-2979. [CrossRef] 